\title{
Respon Pertumbuhan Bibit Kopi Robusta Terhadap Pemberian Pupuk Organik Cair Limbah Industri Tahu
}

\author{
Venti Jatsiyah*, Rosmalinda, Sopiana, Nurhayati \\ Program Studi Budidaya Perkebunan, Politeknik Negeri Ketapang \\ *Email: ventijatsiyah@gmail.com
}

\begin{abstract}
Abstrak
Penelitian berjudul Respon Pertumbuhan Bibit Kopi Robusta (Coffea robusta L) Terhadap Pemberian Pupuk Organik Cair Limbah Industri dilaksanakan di Kebun Percobaan, Politeknik Negeri Ketapang, Kabupaten Ketapang, Kalimantan Barat pada Juli sampai September 2020. Penelitian ini bertujuan untuk mengetahui manfaat pemberian konsentrasi yang berbeda dari POC limbah industri tahu terhadap pertumbuhan bibit kopi robusta. Menggunakan jenis penelitian Rancangan Acak Lengkap (RAL) yang terdiri dari 5 perlakuan dan 4 ulangan, yaitu : K0 = $0 \%, \mathrm{~K} 1=25 \%, \mathrm{~K} 2=50 \%, \mathrm{~K} 3=75 \%$, dan $\mathrm{K} 4=100 \%$. Data yang diperoleh dianalisis menggunakan ANOVA, jika berpengaruh nyata maka dilanjutkan dengan uji DMRT pada taraf $\alpha=0,05$. Hasil penelitian menunjukkan bahwa pemberian POC limbah industri tahu berpengaruh nyata pada parameter tinggi bibit, jumlah daun, panjang akar, berat basah dan berat kering, namun tidak berbeda nyata pada pertambahan diameter batang. Konsentrasi terbaik untuk pertumbuhan bibit kopi robusta adalah $75 \%$.
\end{abstract}

Kata Kunci : limbah tahu, POC, robusta

\section{Pendahuluan}

Kopi (Coffea sp.) merupakan salah satu produk perkebunan di Kalimantan Barat. Lokasi perkebunan kopi banyak berada di Kabupaten Kubu Raya, Kabupaten Sambas, Kabupaten Ketapang, Kabupaten Landak, dan hampir pada semua kabupaten dijumpai ada perkebunan kopi yang diusahakan oleh petani (Ditjenbun, 2016).

Kopi merupakan penghasil devisa terbesar subsektor perkebunan setelah kelapa sawit dan karet. Pada tahun 2001 luas areal penanaman kopi robusta di Indonesia mencapai $1,232,551$ ha, namun mengalami penurunan $25,4 \%$ pada tahun 2018 menjadi 919,501 ha. Sementara luas area penanaman kopi arabika pada tahun 2001 hanya mencapai 82,807 ha dan meningkat sebesar $410,15 \%$ pada tahun 2018 menjadi 339,636 ha. Produktivitas tanaman kopi di Indonesia hanya mencapai $700 \mathrm{~kg} / \mathrm{ha} /$ tahun untuk jenis robusta. Produktivitas dan luas lahan tanaman kopi masih dapat ditingkatkan, mengingat Indonesia merupakan negara beriklim tropis yang cocok untuk jenis tanaman kopi (Ditjenbun, 2017).

Peningkatan produktivitas dapat dilakukan sejak pembibitan. Masa pembibitan merupakan masa yang penting dalam pertumbuhan kopi. Bibit yang baik akan menghasilkan buah kopi yang banyak. Penggunaan pupuk anorganik secara terus menerus akan menyebabkan kerusakan fisik pada tanah. Perlu dicari alternatif pupuk yang dapat diperoleh dengan mudah, tidak mengganggu lingkungan dan pengaruhnya baik untuk pertumbuhan bibit kopi. Limbah cair industri tahu adalah salah satu contoh pupuk organik cair yang diharapkan dapat digunakan sebagai pupuk alternatif untuk meningkatkan pertumbuhan bibit kopi. Limbah cair tahu mengandung unsur hara nitrogen, fospor, dan kalium. Oleh karena itu, limbah cair tahu memiliki potensi untuk dijadikan pupuk organik dengan cara fermentasi dengan menggunakan bioaktivator EM-4 (Rasmito dan Hutomo, 2019). Tujuan dari penelitian ini adalah untuk mengetahui respon bibit kopi dan konsentrasi terbaik pemberian pupuk organik cair dari limbah cair industri tahu terhadap pertumbuhan bibit kopi robusta.

\section{Metodologi}

Penelitian ini dilaksanakan di Kebun Percobaan, Politeknik Negeri Ketapang, Kabupaten Ketapang, Kalimantan Barat, mulai Juli sampai Agustus 2020. Bahan yang digunakan adalah bibit kopi robusta fase kepelan berusia 2 bulan, EM4, gula merah, air bersih, tanah top soil, dan limbah cair industri tahu. Alat yang digunakan pada penelitian ini adalah cangkul, ember, gembor, palu, paku, timbangan, paranet, polibag, gelas ukur, jangka sorong digital, cabinet dryer, alat tulis menulis, meteran, penggaris, dan kamera. Metode yang digunakan pada percobaan ini adalah Rancangan Acak Lengkap (RAL) dengan 5 perlakuan konsentrasi pupuk organik cair dari limbah tahu $\mathrm{K} 0=0 \%, \mathrm{~K} 1=25 \%, \mathrm{~K} 2=50 \%, \mathrm{~K} 3=75 \%$, dan $\mathrm{K} 4=$ $100 \%$. Setiap perlakuan diulang 4 kali sehingga terdapat 20 satuan percobaan.

Parameter yang diamati : tinggi bibit, diameter batang, jumlah daun, panjang akar, berat basah bibit, dan berat kering bibit. dengan tahapan penelitian sebagai berikut :

\subsection{Pembuatan Pupuk Organik Cair Limbah Tahu}

Limbah tahu yang digunakan sebagai POC berasal dari sisa air tahu yang tidak menggumpal bewarna keruh kekuningan yang di dalamnya juga terdapat potongan tahu 
yang hancur karena proses penggumpalan yang tidak sempurna.

Pembuatan POC limbah tahu dilakukan dengan tahapan : mencampurkan $250 \mathrm{ml}$ EM4, 1,25 ml larutan $1 \mathrm{~kg}$ gula merah, dan 37,5 liter limbah cair tahu ke dalam ember, kemudian larutan diaduk hingga tercampur rata dan ember ditutup rapat hingga udara tidak bisa masuk. Pada hari ke3 sampai hari ke-9 tutup ember dibuka setiap hari selama 25 menit sambil melakukan pengadukan, kemudian ditutup kembali. Pada hari ke-15 dilakukan penyaringan pupuk cair hingga didapat larutan yang bersih bebas padatan dan pupuk cair sudah siap digunakan (Aliyenah, et al., 2015).

Pupuk organik cair yang telah jadi ditandai dengan timbulnya gas, wadah menggelembung, terdapat tetes-tetes air, tercium bau aroma tape, warna larutan keruh, ada lapisan berwarna putih baik di permukaan larutan maupun dinding wadah fermentasi (Efelina, et al., 2014). POC limbah tahu yang telah di fermentasikan selama 15 hari bernilai pH 4. Menurut Permentan (2011), standar mutu pupuk organik cair mensyaratkan $\mathrm{pH}$ 4-9.

\subsection{Pembuatan naungan}

Bibit diberikan naungan berupa paranet dengan kerapatan $75 \%$ dengan tinggi atap sebelah Barat $120 \mathrm{~cm}$ dan sebelah Timur $180 \mathrm{~cm}$.

\subsection{Penanaman bibit dalam polybag}

Penanaman bibit kopi menggunakan polybag berukuran $13 \mathrm{~cm}$ x $20 \mathrm{~cm}$. Polybag diisi dengan media tanam top soil sebanyak $3 \mathrm{~kg} /$ polybag, kemudian disiram air hingga basah dan ditugal sedalam $\pm 10 \mathrm{~cm}$. Sebelum ditanam bibit kopi dipotong akarnya 5,0-7,5 cm dari pangkal akar. Setelah bibit ditanam, tanah dipadatkan agar akar tidak menggantung.

\subsection{Aplikasi Pupuk Organik Cair Limbah Tahu}

Pengaplikasian dilakukan seminggu sekali pada pagi hari antara pukul 06:00-07:00 WIB.Konsentrasi POC limbah tahu murni yang digunakan yaitu $80 \mathrm{ml} / \mathrm{kg}$ tanah. Konsentrasi : K0 (tanpa penyiraman pupuk organik cair limbah tahu), K1 (pupuk organik cair limbah tahu sebanyak $25 \%$ dilarutkan dengan air murni sebanyak 75\%), K2 (pupuk organik cair limbah tahu sebanyak 50\% dilarutkan dengan air murni sebanyak 50\%), K3 (pupuk organik cair limbah tahu sebanyak $75 \%$ dilarutkan dengan air murni sebanyak 25\%), dan K4 (pupuk organik cair limbah tahu sebanyak $100 \%$ tanpa penambahan air murni).

\subsection{Pemeliharaan bibit}

Penyiraman dilakukan setiap hari sebanyak dua kali sehari menggunakan gembor dan diusahakan jangan sampai ada genangan air. Waktu penyiraman pagi pukul 06:0007:00 WIB dan sore hari pukul 16:00-17:00 WIB. Jika ditemukan ada gulma yang muncul maka dilakukan pengendalian secara manual dengan mencabut gulma yang ada di dalam dan di luar polybag. Pengendalian hama dan penyakit dilakukan secara manual atau kimiawi apabila ditemukan indikasi yang muncul. Hama yang sering menyerang bibit kopi adalah ulat kilan, belalang, dan bekicot, sedangkan penyakit yang sering dijumpai adalah rebah batang (Rhizoctonia solani) (Harni, et al., 2015).

\section{Hasil}

\subsection{Tinggi Bibit}

Hasil penelitian pada pertambahan tinggi bibit kopi Robusta menunjukkan pemberian POC limbah tahu memberikan pengaruh nyata untuk setiap perlakuan mulai pada usia 3 MSPT (Minggu Setelah Pindah Tanam), 4 MSPT, 5 MSPT, dan 6 MSPT. Seluruh perlakuan tidak memberikan pengaruh nyata terhadap tinggi tanaman pada usia 1 MSPT. Pada usia 2 MSPT perlakuan K1, K2, dan K4 menunjukkan hasil yang sama dan berbeda dengan hasil perlakuan K0 dan K3 namun tidak memberikan hasil berbeda nyata. Hasil uji lanjut DMRT taraf 5\% dapat dilihat pada Tabel 1.

Hal ini dikarenakan tanaman masih muda belum memiliki perakaran yang sempurna sehingga akar belum mampu menyerap unsur hara dengan optimal. Tanaman muda menyerap unsur hara dalam jumlah sedikit, sejalan dengan pertumbuhan tanaman maka kecepatan penyerapan unsur hara tanaman akan meningkat (Ngaisah, 2014).

Tabel 1. Rerata POC limbah tahu terhadap tinggi bibit pada usia 1 MSPT, 2 MSPT, 3 MSPT, 4 MSPT, 5 MSPT, dan 6 MSPT

\begin{tabular}{ccccccc}
\hline \multirow{2}{*}{$\begin{array}{c}\text { Perlak } \\
\text { uan }\end{array}$} & \multicolumn{5}{c}{ Rerata Tinggi Tanaman Pada Setiap Minggu Setelah } \\
\cline { 2 - 7 } Pindah Tanam (MSPT) \\
K0 & $\mathbf{1}$ & $\mathbf{2}$ & $\mathbf{3}$ & $\mathbf{4}$ & $\mathbf{5}$ & $\mathbf{6}$ \\
K1 & $2,56 \mathrm{a}$ & $4,30 \mathrm{~b}$ & $4,26 \mathrm{~d}$ & $5,47 \mathrm{c}$ & $6,57 \mathrm{c}$ & $8,50 \mathrm{~b}$ \\
$\mathrm{~K} 2$ & $2,79 \mathrm{a}$ & $5,97 \mathrm{a}$ & $6,71 \mathrm{bc}$ & $7,99 \mathrm{a}$ & $8,84 \mathrm{ab}$ & $10,00 \mathrm{a}$ \\
$\mathrm{K} 3$ & $2,85 \mathrm{a}$ & $5,83 \mathrm{a}$ & $7,46 \mathrm{ab}$ & $8,72 \mathrm{a}$ & $9,43 \mathrm{a}$ & $10,75 \mathrm{a}$ \\
$\mathrm{K} 4$ & $3,25 \mathrm{a}$ & $4,30 \mathrm{~b}$ & $8,38 \mathrm{a}$ & $8,70 \mathrm{a}$ & $9,30 \mathrm{a}$ & $10,75 \mathrm{a}$
\end{tabular}

Keterangan: Angka-angka yang diikuti dengan huruf yang sama pad a satu kolom tidak berbeda nyata pada DMRT taraf $5 \%$.

Tinggi bibit kopi menunjukkan peningkatan yang berbeda karena pemberian konsentrasi POC yang berbeda selama masa tanam. Pemberian POC limbah tahu konsentrasi $75 \%$ lebih efektif dibandingkan dengan pemberian POC limbah tahu konsentrasi $100 \%$ dikarenakan menunjukkan hasil pertambahan tinggi bibit yang sama. Konsentrasi pupuk yang tinggi menyediakan unsur hara yang cukup pada media tanam. Menurut Rahmah dan Atikah (2014), perbedaan tinggi tanaman disebabkan oleh kemampuan menyerap hara yang berbeda pada setiap tanaman. Semakin tinggi konsentrasi pupuk yang diberikan maka akan lebih cepat meningkatkan perkembangan organ seperti akar, sehingga tanaman dapat menyerap lebih banyak hara dan air yang ada di tanah yang selanjutnya akan mempengaruhi tinggi tanaman, akan tetapi tanaman juga memiliki batas tertentu dalam menyerap hara (Rahmah dan Atikah, 2014).

Kandungan unsur hara pada hasil fermentasi limbah tahu yaitu $\mathrm{N}$, P, dan $\mathrm{K}$ yang bisa memenuhi kebutuhan tanaman. Protein dalam limbah tahu padat maupun limbah cair tahu dalam tanah jika terurai oleh mikroba tanah akan melepaskan senyawa $\mathrm{N}$ yang akhirnya akan diserap oleh akar tanaman. Unsur N sangat penting sebagai komponen 
utama dalam sintesa protein yang dilakukan oleh sel tumbuhan (Suhendra dan Armani, 2017).

Pemberian POC limbah tahu dengan konsentrasi berbeda menunjukkan pertambahan tinggi bibit lebih baik setiap minggunya dibandingkan pada perlakuan kontrol yang menunjukkan pertambahan tinggi terendah. Hal ini dikarenakan ketersediaan hara dalam tanah belum memenuhi kebutuhan unsur hara tanaman untuk pertumbuhan vegetatif diantaranya tinggi tanaman. Menurut Perwitasari dan Balia (2012), nitrogen diserap tanaman dalam bentuk $\mathrm{NO}^{3-}$ (nitrat) dan $\mathrm{NH}^{4+}$ (ammonium). Fungsi $\mathrm{NH}^{4+}$ (ammonium) pada pertumbuhan tanaman akan menyebabkan tanaman tumbuh dengan pesat, sel-sel membesar dan tahan terhadap penyakit, tanaman yang kurang unsur hara nitrogen pertumbuhannya akan terhambat serta menurunkan daya tahan terhadap serangan penyakit seperti pada perlakuan media tanpa pemberian nutrisi.

\subsection{Diameter Batang}

Hasil penelitian pada pertambahan diameter batang bibit kopi Robusta menunjukkan bahwa bibit yang diberi POC limbah tahu dengan konsentrasi yang berbeda dan bibit tanpa pemberian POC limbah tahu tidak berpengaruh nyata. Hasil uji lanjut DMRT taraf 5\% dapat dilihat pada Tabel 2.

Tabel 2. Rerata diameter batang pada usia 1 MSPT, 2, MSPT, 3 MSPT, 4 MSPT, 5 MSPT, dan 6 MSPT

\begin{tabular}{ccccccc}
\hline \multirow{2}{*}{ Perlakuan } & \multicolumn{6}{c}{$\begin{array}{c}\text { Diameter Batang Pada Setiap Minggu Setelah } \\
\text { Pindah Tanam (MSPT) }\end{array}$} \\
\cline { 2 - 7 } & $\mathbf{1}$ & $\mathbf{2}$ & $\mathbf{3}$ & $\mathbf{4}$ & $\mathbf{5}$ & $\mathbf{6}$ \\
\hline K0 (0\%) & $1,00 \mathrm{a}$ & $1,06 \mathrm{a}$ & $0,72 \mathrm{a}$ & $1,16 \mathrm{a}$ & $1,16 \mathrm{a}$ & $1,16 \mathrm{a}$ \\
$\mathrm{K} 1(25 \%)$ & $1,00 \mathrm{a}$ & $0,72 \mathrm{a}$ & $0,69 \mathrm{a}$ & $0,97 \mathrm{a}$ & $1,25 \mathrm{a}$ & $1,25 \mathrm{a}$ \\
$\mathrm{K} 2(50 \%)$ & $1,00 \mathrm{a}$ & $0,89 \mathrm{a}$ & $0,91 \mathrm{a}$ & $1,04 \mathrm{a}$ & $1,04 \mathrm{a}$ & $1,04 \mathrm{a}$ \\
$\mathrm{K} 3(75 \%)$ & $1,00 \mathrm{a}$ & $0,62 \mathrm{a}$ & $0,73 \mathrm{a}$ & $1,02 \mathrm{a}$ & $1,27 \mathrm{a}$ & $1,50 \mathrm{a}$ \\
$\mathrm{K} 4(100 \%)$ & $1,00 \mathrm{a}$ & $0,97 \mathrm{a}$ & $0,79 \mathrm{a}$ & $1,02 \mathrm{a}$ & $1,27 \mathrm{a}$ & $1,50 \mathrm{a}$
\end{tabular}

Keterangan : Angka-angka yang diikuti dengan huruf yang sama pada satu kolom tidak berbeda nyata pada DMRT taraf 5\%

Pada tabel terlihat bahwa pemberian POC limbah tahu menunjukkan hasil tidak berbeda nyata antar perlakuan. Hal ini dikarenakan bibit kopi memiliki kecepatan tumbuh lingkar batang yang lambat sehingga belum mampu meningkatkan pertambahan lingkar batang dalam waktu yang relatif singkat. Pada tanaman tahunan seperti tanaman perkebunan mengalami pertumbuhan yang lama kearah horizontal sehingga untuk pertambahan lingkar batang pada tanaman perkebunan membutuhkan waktu yang relatif lama (Lindawati, 2012).

Besarnya diameter batang berhubungan erat dengan ketersediaan unsur hara dalam tanah yang dibutuhkan tanaman. Kusuma (2014), mengatakan tanaman dapat tumbuh serta mampu memberikan hasil yang lebih baik jika tumbuh pada tanah yang cukup kuat menunjang tegaknya tanaman, tidak mempunyai lapisan penghambat perkembangan akar, aerasi baik, kemasaman sekitar netral, tidak mempunyai kelarutan garam yang tinggi, cukup tersedia unsur hara dan air dalam kondisi yang seimbang.

Kandungan unsur hara yang penting untuk tanaman antara lain unsur $(\mathrm{N})$, posfor $(\mathrm{P})$, dan Kalium (K). Ketiga jenis unsur hara ini sangat penting diberikan karena masingmasing memiliki fungsi yang sangat penting bagi pertumbuhan tanaman. Namun unsur K lebih banyak dibutuhkan tanaman dalam proses pembesaran lingkar batang. Unsur $\mathrm{K}$ memiliki peranan dalam pembentukan Adenosin Trifosfat (ATP) yang dibutuhkan dalam pembesaran dan perpanjangan sel. Tersedianya unsur $\mathrm{K}$ dalam jumlah yang cukup menyebabkan kegiatan metabolisme tanaman akan meningkat sehingga terjadi pembesaran pada bagian batang (Suhendra dan Armani, 2017).

\subsection{Jumlah Daun}

Hasil penelitian pada pertambahan jumlah daun menunjukkan bahwa bibit kopi Robusta yang diberikan POC limbah tahu berpengaruh nyata untuk setiap perlakuan. Hasil uji lanjut DMRT taraf 5\% dapat dilihat pada Tabel 3.

Tabel 3. Rerata POC limbah tahu terhadap jumlah daun pada usia 1 MSPT, 2 MSPT, 3 MSPT, 4 MSPT, 5 MSPT, dan 6 MSPT

\begin{tabular}{lcccccc}
\hline \multirow{2}{*}{ Perlakuan } & \multicolumn{7}{c}{ Jumlah Daun Pada Setiap Minggu Setelah Pindah } \\
& \multicolumn{7}{c}{ Tanam (MSPT) } & $\mathbf{5}$ & $\mathbf{6}$ \\
\hline & $\mathbf{1}$ & $\mathbf{2}$ & $\mathbf{3}$ & $\mathbf{4}$ & $\mathbf{5}$ & $\mathbf{6}$ \\
\hline K0 $(0 \%)$ & $2,00 \mathrm{a}$ & $2,50 \mathrm{~b}$ & $3,00 \mathrm{c}$ & $4,25 \mathrm{~b}$ & $5,00 \mathrm{c}$ & $5,00 \mathrm{c}$ \\
K1 (25\%) & $2,00 \mathrm{a}$ & $3,25 \mathrm{a}$ & $4,00 \mathrm{~b}$ & $5,25 \mathrm{a}$ & $5,50 \mathrm{~b}$ & $5,50 \mathrm{~b}$ \\
K2 (50\%) & $2,00 \mathrm{a}$ & $3,50 \mathrm{a}$ & $5,00 \mathrm{a}$ & $5,50 \mathrm{a}$ & $6,00 \mathrm{a}$ & $6,00 \mathrm{a}$ \\
K3 (75\%) & $2,00 \mathrm{a}$ & $3,75 \mathrm{a}$ & $5,50 \mathrm{a}$ & $6,00 \mathrm{a}$ & $6,00 \mathrm{a}$ & $6,00 \mathrm{a}$ \\
K4 (100\%) & $2,00 \mathrm{a}$ & $4,00 \mathrm{a}$ & $5,50 \mathrm{a}$ & $5,75 \mathrm{a}$ & $6,00 \mathrm{a}$ & $6,00 \mathrm{a}$
\end{tabular}

Keterangan: Angka-angka yang diikuti dengan huruf yang sama pada satu kolom tidak berbeda nyata pada DMRT taraf $5 \%$

Pada tabel diatas menunjukkan bahwa pemberian POC limbah tahu dapat meningkatkan pertambahan jumlah daun bibit kopi robusta. Pemberian POC limbah tahu menunjukkan pertambahan jumlah daun tertinggi sebanyak 7 helai yaitu pada konsentrasi $75 \%$ di usia 6 MSPT. Hal ini dikarenakan pemberian pupuk dengan dosis yang sesuai dengan kebutuhan tanaman akan diserap oleh tanaman secara efektif sehingga dapat meningkatkan pertumbuhan vegetatif tanaman, salah satunya adalah pertumbuhan daun. Menurut hasil penelitian Nurman dan Zuhry (2017), pemberian POC limbah tahu $75 \%$ nyata lebih banyak menghasilkan jumlah daun dibandingkan dengan tanpa pemberian POC limbah tahu, dan POC limbah tahu 25\%, tetapi tidak berbeda nyata dengan pemberian POC tahu $50 \%$.

Semakin tinggi dosis pupuk yang diberikan maka kandungan unsur hara yang diterima oleh tanaman akan semakin tinggi. Begitu pula dengan semakin seringnya frekuensi aplikasi pupuk yang dilakukan pada tanaman maka kandungan unsur hara juga semakin tinggi. Namun pemberian dengan dosis yang berlebihan justru akan mengakibatkan tanaman tumbuh tidak dapat tumbuh dengan baik. Menurut penelitian Rahmawati (2014), penyiraman pupuk cair dari air limbah tahu dengan konsentrasi $75 \%$ memberikan pengaruh nyata terhadap jumlah daun tanaman sawi. 
Perlakuan tanpa pemberian limbah menunjukkan pertambahan jumlah daun terendah yaitu 5 helai. Hal ini karena tidak tersedianya unsur hara yang cukup untuk digunakan pertumbuhan vegetatif, sehingga jumlah daun lebih rendah dibanding tanaman yang diberi perlakuan POC limbah tahu. Menurut Suhendra dan Armani (2017), unsur hara yang didapatkan melalui pemupukan akan memberikan efek fisiologis terhadap penyerapan unsur hara oleh perakaran tanaman sehingga pertumbuhan tanaman menjadi lebih baik. Pembentukan daun berkaitan dengan tinggi tanaman, dimana jumlah daun dipengaruhi oleh tinggi batang. Semakin tinggi batang, maka jumlah daun yang terbentuk juga semakin meningkat. Pada perlakuan pemberian POC limbah tahu menunjukkan perlakuan dengan kecenderungan pertambahan tinggi tanaman diikuti dengan pertambahan jumlah daun yang banyak 2-7 helai.

Unsur Nitrogen yang terdapat pada POC limbah tahu menyebabkan terbentuknya asam amino sebagai kerangka protein sehingga proses pembelahan, pembesaran serta perpanjangan sel dapat berjalan lancar. Nitrogen juga berperan dalam pembentukan butir hijau daun yang merupakan faktor keharusan berlangsungnya fotosintesis. Menurut Sinaga (2018), hasil fotosintesis sebagian digunakan untuk menyusun jaringan tanaman dan sebagiannya lagi digunakan untuk kegiatan metabolisme tanaman.

\subsection{Panjang Akar}

Hasil penelitian menunjukkan bahwa pemberian POC limbah tahu yang berbeda konsentrasi berpengaruh nyata pada panjang akar bibit kopi Robusta. Data hasil uji lanjut DMRT taraf 5\% dapat dilihat pada Tabel 4.

Tabel 4. Rerata panjang akar akibat pemberian POC limbah tahu

\begin{tabular}{lc}
\hline \multicolumn{1}{c}{ Perlakuan } & Panjang akar \\
\hline K0 $(0 \%)$ & $6,75 \mathrm{~b}$ \\
K1 $(25 \%)$ & $10,25 \mathrm{ab}$ \\
K2 $(50 \%)$ & $10,50 \mathrm{ab}$ \\
K3 $(75 \%)$ & $12,50 \mathrm{a}$ \\
K4 $(100 \%)$ & $11,75 \mathrm{a}$
\end{tabular}

Keterangan: Angka-angka yang diikuti dengan huruf yang sama pada satu kolom tidak berbeda nyata pada DMRT taraf $5 \%$

Pemberian POC limbah tahu konsentrasi $75 \%$ menunjukkan hasil tertinggi diantara perlakuan lainnya. Hal ini dikarenakan karakteristik pertumbuhan kopi sebagai jenis tanaman perkebunan memerlukan waktu relatif lebih lama dibandingkan jenis tanaman lain, terlebih pada usia muda perakaran belum mampu menyerap unsur hara dengan optimal. Tanaman muda menyerap unsur hara dalam jumlah sedikit, sejalan dengan pertumbuhan tanaman maka kecepatan penyerapan unsur hara tanaman akan meningkat (Ngaisah, 2014).

Selama proses pertumbuhan dan perkembangannya tanaman membutuhkan unsur-unsur hara. Terutama unsur hara makro seperti fosfor $(\mathrm{P})$, kalium $(\mathrm{K})$, dan nitrogen $(\mathrm{N})$ yang bertujuan untuk mempercepat pertumbuhan akar dan meningkatkan perkembangan suatu tanaman. Menurut
Rinekso et al. (2011), unsur fospor bagi tanaman lebih banyak berfungsi untuk merangsang pertumbuhan akar, khususnya akar tanaman muda. Menurut Sinaga (2018), pembelahan sel pada fase vegetatif terjadi pada pembuatan sel-sel baru terutama pada jaringan-jaringan meristematik titik tumbuh batang dan akar. Sel-sel baru ini memerlukan karbohidrat dalam jumlah besar, karena dinding-dindingnya terbuat dari selulosa dan protoplasma kebanyakan terbuat dari gula sehingga bila faktor-faktor lain tersedia dalam keadaan seimbang maka laju pembelahan sel tergantung pada persediaan karbohidrat. Nitrogen membentuk asam amino sebagai kerangka protein sehingga proses pembelahan, pembesaran, dan perpanjangan sel dapat berjalan lancar.

Tanaman dapat tumbuh dengan baik juga didukung oleh kondisi dan sifat tanah yang baik sehingga tanaman dapat menggunakan hara dalam tanah secara maksimal. Selain itu pertumbuhan tanaman juga dipengaruhi oleh faktor eksternal seperti ketersediaan unsur hara dalam media tanam, cahaya, suhu, kelembapan, dan $\mathrm{pH}$. Pada pengukuran $\mathrm{pH}$ POC limbah tahu diperoleh nilai yaitu 4 yang merupakan standar minimun untuk mutu pupuk organik cair menurut Permentan (2011). Tanaman kopi Robusta dapat tumbuh optimal pada $\mathrm{pH}$ antara 5,5-6,5. Apabila nilai $\mathrm{pH}$ kurang dari 5,5 atau lebih dari 6,5 maka daya larut unsur hara tidak sempurna lagi sehingga sulit diserap oleh akar tanaman.

\subsection{Berat Basah dan Berat Kering Bibit}

Hasil penelitian menunjukkan bahwa pemberian POC limbah tahu dengan konsentrasi yang berbeda memberikan hasil berpengaruh nyata pada berat basah dan berat kering bibit kopi Robusta. Hasil uji lanjut DMRT taraf 5\% dapat dilihat pada Tabel 5.

Tabel 5. Rerata berat basah dan berat kering bibit akibat aplikasi POC limbah tahu

\begin{tabular}{cccc}
\hline Perlakuan & Konsentrasi & $\begin{array}{c}\text { Berat basah } \\
\text { bibit }\end{array}$ & $\begin{array}{c}\text { Berat kering } \\
\text { bibit }\end{array}$ \\
\hline K0 & $0 \%$ & $0,46 \mathrm{~b}$ & $0,14 \mathrm{c}$ \\
$\mathrm{K} 1$ & $25 \%$ & $0,67 \mathrm{a}$ & $0,22 \mathrm{~b}$ \\
$\mathrm{~K} 2$ & $50 \%$ & $0,74 \mathrm{a}$ & $0,27 \mathrm{a}$ \\
$\mathrm{K} 3$ & $75 \%$ & $0,72 \mathrm{a}$ & $0,29 \mathrm{a}$ \\
$\mathrm{K} 4$ & $100 \%$ & $0,74 \mathrm{a}$ & $0,27 \mathrm{ab}$ \\
\hline Keterangan: Angka-angka yang diikuti dengan huruf yang sama pada satu \\
\multicolumn{4}{c}{ kolom tidak berbeda nyata pada DMRT taraf 5\% }
\end{tabular}

Pada tabel terlihat bahwa pemberian POC limbah tahu menunjukkan berat basah tertinggi pada konsentrasi $50 \%$ dan $100 \%$ dengan hasil yang sama yaitu 0,74 gr. Pada bibit yang tidak diberikan POC limbah tahu menunjukkan hasil terendah dari seluruh perlakuan lainnya, yaitu sebesar 0,47 gr. Hal ini dikarenakan kandungan unsur hara POC limbah tahu berperan aktif dalam tanaman sehingga bisa meningkatkan berat basah bibit tersebut.

Menurut Lakitan (2011), berat basah tanaman tergantung pada kadar air yang berada di dalam jaringan tanaman. Munawar (2011), menambahkan bahwa ketersediaan hara dalam jumlah yang cukup dan optimal juga berpengaruh terhadap pertumbuhan dan perkembangan tanaman, sehingga bisa menghasilkan produksi yang sesuai dengan potensinya. Semakin besar ketersediaan unsur hara di dalam tanah yang diserap oleh tanaman mengakibatkan 
meningkatnya proses fisiologi dan metabolisme sehingga dapat meningkatkan jumlah sel di dalam tanaman. Sel akan membentuk jaringan yang baik dan akan membentuk organ yang baik pula.

Berat basah bibit tanpa pemberian POC limbah tahu menunjukkan hasil terendah diantara perlakuan lainnya. Hal ini diduga bahwa kandungan unsur hara untuk tanaman rendah, sehingga menyebabkan pertumbuhan kurang optimal. Berat basah tanaman dipengaruhi oleh sistem perakaran pada tanaman tersebut. Sistem perakaran tanaman berfungsi dalam penyerapan unsur hara dan penunjang pembentukan organ tanaman. Sistem perakaran tanaman yang masih muda belum bisa berfungsi optimal. Hal tersebut sesuai dengan hasil penelitian Perwitasari dan Balia, (2012) yang menyatakan pada umur 1 minggu setelah tanam akar tanaman masih beradaptasi dengan kondisi media, sehingga tanaman akan mengalami stres. Sedangkan pada umur 2, 3, dan 4 minggu setelah tanam akar tanaman sudah mampu beradaptasi dan dapat mendistribusikan unsur hara dari media ke tanaman yang akan mendukung tanaman dalam menghasilkan daun baru untuk proses fotosintesis.

Semakin baik hara yang terserap oleh tanaman maka ketersediaan bahan dasar bagi proses fotosintesis akan semakin baik pula. Fotosintesis yang berlangsung baik akan memicu peningkatan jumlah karbohidrat dan protein pada organ tubuh tanaman. Peningkatan jumlah karbohidrat dan protein sebagai akumulasi hasil proses fotosintesis yang akan berpengaruh pada berat basah tanaman (Fitrianah, et al., 2012).

Pada tabel terlihat bahwa pemberian POC limbah tahu konsentrasi $75 \%$ memberikan hasil tertinggi pada berat kering yaitu sebesar 0,29 gr. Pada bibit yang tidak diberikan POC limbah tahu menunjukkan hasil terendah dari seluruh perlakuan lainnya, yaitu sebesar 0,14 gr. Hal ini dikarenakan kandungan unsur hara POC limbah tahu berperan aktif dalam tanaman sehingga bisa meningkatkan berat kering bibit tersebut.

Berat kering merupakan hasil dari pengeringan dimana seluruh air yang terdapat dalam jaringan tanaman telah menguap seluruhnya. Pemberian pupuk dengan dosis dan cara yang tepat bisa membuat pertumbuhan tanaman optimal. Jika pupuk organik cair diberikan langsung tanpa pengenceran dapat berdampak kurang baik terhadap pertumbuhan tanaman, seperti keracunan dan dapat juga menyebabkan terjadinya klorisis dan nekrosis sehingga menyebabkan tanaman mati. Menurut pernyataan Rosmarkam dan Yuwono (2011), penggunaan pupuk dengan kepekatan dua kali lipat dari yang dianjurkan akan menyebabkan kerusakan pada tanaman.

POC limbah tahu mengandung unsur kalium yang berpengaruh terhadap bobot kering tanaman. Ketersediaan kalium berperan dalam pembentukan perakaran baru yang nantinya digunakan untuk penyerapan air dan unsur hara dalam tanah sehingga bisa meningkatkan proses fotosintesis. Glukosa hasil fotosintesis pada tanaman diubah menjadi nutrisi seperti lemak dan protein. Tumbuhan menyimpan glukosa dalam bentuk pati dan sisa cadangan glukosa disimpan di buah, perakaran, dan daun.

Asimilat yang lebih besar memungkinkan pembentukan biomassa tanaman yang lebih besar yang berhubungan pula dengan berat kering yang dihasilkan. Menurut Lakitan
(2017), bahwa berat kering tanaman merupakan cerminan dari kemampuan tanaman tersebut dalam menyerap unsur hara yang ada. Jika kemampuan tanaman dalam menyerap unsur hara lebih tinggi, maka proses fisiologi yang terjadi dalam tanaman terutama translokasi unsur hara dan hasil fotosintesis akan berjalan dengan baik sehingga organ tanaman akan menjalankan fungsinya dengan baik pula.

Dukungan penerapan pemupukan yang sesuai akan mampu meningatkan pertumbuhan dan perkembangan tanaman. Pemberian pupuk yang sedikit bisa menyebabkan tanaman kekurangan unsur hara, namun pemberian pupuk berlebihan juga dapat menyebabkan kematian pada tanaman. Waktu dan cara pemberian pupuk yang tepat juga sangat penting terutama pada saat ketersediaan pupuk terbatas. Pemberian pupuk yang terlalu sering akan menyia-nyiakan perlakuan pemupukan sehingga terjadi pemborosan dan tidak efisien. Penggunaan pupuk haruslah tepat waktu dan tepat cara pengaplikasiannya sehingga bisa meningkatkan hasil seoptimal mungkin

\section{Kesimpulan}

Berdasarkan hasil dan pembahasan maka dapat disimpulkan bahwa pemberian POC limbah industri tahu berpengaruh nyata terhadap parameter tinggi bibit, jumlah daun, panjang akar, berat basah bibit, dan berat kering bibit kopi robusta. Tetapi pemberian POC limbah industri tahu tidak menunjukkan hasil berpengaruh nyata terhadap parameter diameter batang bibit kopi robusta. Konsentrasi terbaik POC limbah industri tahu untuk pertumbuhan bibit kopi robusta adalah $75 \%$.

\section{Daftar Pustaka}

Aliyenah, A. Napoleon, Yudono, B., 2015. Pemanfaatan limbah cair industri tahu sebagai pupuk cair organik terhadap pertumbuhan dan produksi tanaman kangkung darat (Ipomoea reptans P.). Jurnal Penelitian Sains 17 (3), 102-110.

Direktorat Jenderal Perkebunan. 2016. Statistik perkebunan. http://ditjenbun.pertanian.go.id. Diakses : 5 Agustus 2020.

Direktorat Jenderal Perkebunan. 2017. Statistik perkebunan Indonesia. http://ditjenbun.pertanian.go.id. Diakses : 5 Agustus 2020.

Efelina, V., Purwanti, E., Dampang, S., Rahmadewi, R., 2014. Sosialisasi pembuatan pupuk organik cair dari batang pohon pisang di Desa Mulya Jaya Kecamatan Teluk Jambe Timur Kabupaten Karawang. Jurnal Senadimas 1 (2), 357-359.

Fitrianah, Listin, Fatimah, Siti, Hidayati, Yunin, 2012. Pengaruh komposisi media tanam terhadap pertumbuhan dan kandungan saponin pada dua varietas tanaman gendola (Basella sp.). Jurnal Agrovivor 5 (1), 36-46.

Harni, R., Samsudin. Amaria, W. Indriati, G. Soesanthy, F. Khaerati. Taufiq, E. Hasibuan, A.M. dan Hapsari. A.D., 2015. Teknologi pengendalian hama dan penyakit tanaman kopi. http://repository.pertanian.go.id. Diakses : 6 Agustus 2020.

Kusuma, E.M., 2014. Respon rumput gajah (Pennisetum purpureum) terhadap pemberian pupuk majemuk. Jurnal Ilmu Hewani Tropika 3 (1), 6-11.

Lakitan, B. 2011. Dasar-Dasar Fisiologi Tumbuhan. Rajagrafindo Persada, Jakarta.

Lindawati. 2012. Pengantar Agronomi. PT. Gramedia, Jakarta.

Munawar. A. 2011. Kesuburan Tanaman dan Nutrisi Tanaman. IPB Press, Bogor.

Ngaisah, S. 2014. Pengaruh Kombinasi Limbah Cair Tahu dan Kompos Sampah Organik Rumah Tangga pada Pertumbuhan dan Hasil 
Panen Kailan (Brassica oleracea Var. Acephala). Skripsi. Jurusan Biologi Fakultas SAINTEK. UIN Maulana Malik Ibrahim Malang. Nurman, Zuhry, E., Isna, R.D., 2017. Pemanfaatan ZPT air kelapa dan POC limbah tahu untuk pertumbuhan dan produksi bawang merah (Allium ascalonicum L.). Jurnal Online Mahasiswa Fakultas Pertanian Universitas Riau 4 (2), 1-5.

Peraturan Menteri Pertanian. 2011. Pupuk Organik, Pupuk Hayati, dan Pembenah Tanah. https://www.academia.edu. Diakses 10 Oktober 2019.

Perwitasari, B, Tripatmasari, M.,Wasonowati, C., 2012. Pengaruh media tanam dan nutrisi terhadap pertumbuhan dan hasil tanaman pakchoi (Brassica juncea L.) dengan sistem hidroponik. Jurnal Agrovigor 5 (1), 8-9.

Rahmah, A., Izzati, M., 2014. Pengaruh pupuk organik cair berbahan dasar limbah sawi putih (Brassica chinensis L.) terhadap pertumbuhan tanaman jagung manis (Zea mays L.). Buletin Anatomi dan Fisiologi 22 (1), 5-17.

Rahmawati, 2014. Pengaruh frekuensi dan konsentrasi penyiraman air limbah pembuatan tahu terhadap pertumbuhan tanaman sawi (Brassica juncea L.). Jurnal Lentera 14 (11), 15-23.

Rasmito, A., Hutomo, A., Hartono, A.P., 2019. Pembuatan pupuk organik cair dengan cara fermentasi limbah cair tahu, starter filtrat kulit pisang dan kubis, dan bioaktivator EM4. Jurnal IPTEK 23 (1), 5562 .

Rinekso, B.K., Sutrisno, K.,Sumiyati, S. 2011. Studi Pembuatan Pupuk Organik Cair dari Fermentasi Urine Sapi dengan Variasi Lokasi Peternakan yang Berbeda. https://www.enveng.undip.ac.id. Diakses 16 Juli 2020.

Rosmarkam, A.,Yuwono, N.W. 2011. Ilmu Kesuburan Tanah. Kanisius, Yogyakarta.

Sinaga, M., 2018. Pengaruh limbah cair tahu terhadap pertumbuhan dan hasil tanaman mentimun (Cucumis sativus .L). Jurnal PIPER 14 (26), 308-312.

Suhendra, I., Armaini., 2017. Aplikasi Beberapa Hasil fermentasi limbah terhadap pertumbuhan bibit kopi robusta (Coffea canephora Pierre). Jurnal Online Mahasiswa Fakultas Pertanian Universitas Riau 4 (2), 1-12. 